\title{
A DECADE OF AFRICAN UNION AND EUROPEAN UNION TRANS-REGIONAL SECURITY RELATIONS
}

\author{
Glen Segell \\ Director, London Security Policy Study
}

\begin{abstract}
The first decade of the new millennium saw the European Union deploy nine security missions to the African continent, quoting the European Security and Defence Policy. Unlike the numerous United Nations security missions that European states had previously contributed to, these were part of a grand strategy designed to link the African Union and the European Union in a process of transregionalism defined as a unique organisational infrastructure (joint secretariat for research, policy planning, preparation and coordination of meetings and implementation of decisions). The rationale being that security and its associated peace and stability are the basis for sustainable development in other areas. This article follows the development of the trans-regionalism detailing the security missions.
\end{abstract}

\section{Introduction}

In the post-colonial and post-Cold War period of the $20^{\text {th }}$ century, the United States, France, the United Kingdom and others deployed security missions to Africa sometimes as part of United Nations (UN) missions and sometimes individually. UN missions rarely had a mandate for the use of intervening force, known as 'Chapter 7'. Some missions emerged from specific foreign policy objectives or security needs such as the United States involvement in Somalia (1992-1994), the United Kingdom in Sierra Leone (2000) and France in Chad (ongoing). Other missions were reactive to specific crisis situations designed to stabilise a process leading to conflict resolution such as in the Congo (1960-1964). No overriding grand strategy was present for a comprehensive plan for peace and stability on the entire African continent. The African Union (AU), formed from its predecessor the Organisation of 
African Unity, was a catalyst for change. ${ }^{1}$ The AU as part of its agenda promoted security and stability as a prerequisite for development and integration on a continental-wide basis with the legitimacy and authority, from its Constitutive Act, to intervene in a member state. ${ }^{2}$

The AU African Peace and Security Architecture, created for furthering the goal of continental-wide security and stability, envisaged sub-regional organisational infrastructures contributing to an African Standby Brigade deployable at both subregional and continental levels encompassing military, police and civilian components. The success of the Economic Community of West African States (ECOWAS) in the implementation of the multi-lateral Economic Community of West African States Monitoring Group (ECOMOG), which intervened in the civil war in Liberia (1989-1996), gave hope that such a strategy could succeed. ${ }^{3}$

The immediate implementation was beyond reach of the AU due to a lack of continental-wide experience in such types of security missions, and due to the lack of available equipment for extended logistics such as airlift on a continental-wide basis. The United States, the United Kingdom and France, with experience and capability to assist, were approached to provide training and logistics, as were the UN, NATO and the European Union (EU). Understanding why these would assist requires an acceptance that it would benefit their interests. It also requires an acceptance that there must be some common values. Authors such as Amitai Etzioni, David Held and Anthony McGrew, John Steinbruner, Joseph Nye and John Donahue have noted that regionalisation - and by inference trans-regionalisation - cannot take place in the absence of common values. ${ }^{4}$

1 The AU is an intergovernmental organisation of 53 African states promoting cooperation consisting of an assembly, executive council, pan-African parliament, court of justice, commission, and various councils, committees and institutions.

${ }^{2}$ Africa Union, Constitutive Act, 11 July 2000, Lome Togo available at

http://www.africa-union.org/root/au/AboutAu/Constitutive_Act_en.htm

${ }^{3}$ ECOWAS a regional group of 16 countries founded in 1975 to promote economic cooperation consisting of a commission, community parliament, court of justice and bank for investment and development. ECOMOG was an ad hoc military formation from its members.

${ }^{4}$ Amitai Etzioni, From Empire to Community (New York: Palgrave MacMillan, 2004), David Held and Anthony McGrew (eds) Governing Globalisation: Power, Authority, and Global Governance, (Malden Mass: Blackwell Publishers, 2002), John D. Steinbruner, Principles of Global Security 
The EU and its member states agreed to collaborate with the AU partly because of their believed historical obligation and partly because they believed African stability as being essential to European security, especially in areas such as terrorism, drug and human trafficking and migration. ${ }^{5}$ The common value being that security is the basic pre-condition for sustainable development. This EU and AU collaboration provides a unique account of two regional fora engaged in a step-bystep process of dialogue and cooperation resulting in a grand strategy for Africawide peace and stability. This article will continue by detailing the policy decisions, the security missions in combined, joint and hybrid force structures in varying forms and the development of the unique trans-regional organisational infrastructure. ${ }^{6}$

\section{Bi-lateral inter-regionalism and trans-regionalism}

EU collaboration with the $\mathrm{AU}$ is not unique. A previous article published in Scientia Militaria demonstrated the specific assistance provided to the AU by NATO for the AU Mission in Sudan (AMIS), (April 2005 to December 2007). ${ }^{7}$ That article applied the theoretical underpinning of bilateral inter-regionalism defined as groupto-group exchanges of information and cooperation (projects) in specific policy, based on a low level of institutionalisation, with no common overarching institutions, and both sides exclusively relying on their own institutional infrastructure. ${ }^{8}$ In this fashion, NATO assistance was similar to UN missions legitimised by UN Security Council Resolutions granting each mission a specific mandate, budget, force structure, length of deployment, and equipment. The

(Washington D.C. Brookings Institute Press, 2000), Joseph Nye and John Donahue (eds), Governance in a Globalising World (Washington D.C. Brookings Institute Press, 2000).

${ }^{5}$ Factsheet on EU support for peace and security in Africa, February 2005 available at http://www.consilium.europa.eu/showPage. $\operatorname{aspx}$ ?id=400\&lang=en\&mode $=\mathrm{g}$

${ }^{6}$ Primary sources cited in this article can be accessed on the Internet. Should the links no longer be active or should readers prefer hard copies then the same European Union sources are available at European Union Depository Libraries world-wide while copies of these as well as AU, NATO and United Nations sources are also available on request from the respective public diplomacy or press offices.

7 Glen Segell, "The first NATO mission to Africa: Darfur", Scientia Militaria, Volume 36 Number 2 (2008) pp.1-18.

${ }^{8}$ Jürgen Rüland, Inter- and Transregionalism: "Remarks on the state of the art of a new research agenda", National Europe Centre Paper No. 35, available at http://www.anu.edu.au/NEC/Archive/ruland2.pdf 
structure of each UN mission differs even if individual soldiers or their units might have been deployed to previous UN missions and thus offering a learning curve on the tactical level.

This article constructs further considering the range of security activities and relations that could be described as trans-regionalism that is applicable to EU and AU interactions. Trans-regionalism, when compared to bilateral inter-regionalism, is defined as a situation where the agenda and relations have grown in complexity requiring trans-regional fora, a unique organisational infrastructure (secretariat for research, policy planning, preparation and coordination of meetings and implementation of decisions) that comprises states from more than one region.

The nature of the organisational infrastructure is significant in defining trans-regional security since there is no clearly agreed definition on the size or nature of a region. An example of a trans-regional security organisation is NATO, comprising 28 states from Europe and North America in its own unique organisation. Africa is a region (continental) consisting of 53 sovereign states where the $\mathrm{AU}$, through its Constitutive Act, has the legitimacy to construct an organisational infrastructure of security affairs. Within Africa there are subcontinental regional organisations having security infrastructures that work with each other. For example, the Southern African Development Community (SADC) operates within its own region, as does the Economic Community of West African States (ECOWAS). ${ }^{9}$ Both also interact in Africa-wide peacekeeping within the AU.

The SADC has a Regional Indicative Strategic Plan (RISDP) and a Strategic Indicative Plan for the Organ (SIPO) aimed at deeper regional integration and poverty eradication, which include an organisational framework for "peace, political stability and security in the region". ${ }^{10}$ The SADC has regional peacekeeping training

${ }^{9}$ The SADC, formed in 1980 as a loose alliance of nine majority-ruled states, aimed to coordinate development projects to lessen economic dependence on Apartheid South Africa. Since 1992, it has enlarged to 15 states, including South Africa, and migrated into a development community to facilitate a free trade area, customs union, common market, monetary union, and single currency. Its policy organs and institutions include a summit, organ on politics, defence and security, tribunal, council of ministers, national committees, standing committee of senior officials, secretariat, policy leadership system, and troikas.

10 SADC Secretariat, SADC Regional Indicative Strategic Plan, March 2003, available at http://www.sarpn.org.za/documents/d0000294/index.php 
centres and is in the process of establishing a regional standby brigade, as part of the goal to contribute to the AU Standby Force. This is in accordance with Article 13 of the Protocol establishing the Peace and Security Council of the African Union within the concept of the African Peace and Security Architecture, guided by the UN peacekeeping framework. ${ }^{11}$

Another sub-regional organisational infrastructure along these lines is the Intergovernmental Authority on Development (IGAD) in Eastern Africa, which is also working with the SADC and ECOWAS as part of the AU security organisational infrastructure. ${ }^{12}$ In these efforts, the SADC is not confined to working within Africa but is also engaged in trans-regional relations with bi-lateral partners (Denmark, Finland, France, Germany, Japan, Netherlands, Sweden, Switzerland, UK, USA) and with multi-lateral partners such as the African Development Bank (ADB), European Commission (EC), European Investment Bank (EIB), Food and Agricultural Organisation (FAO), and the United Nations Development Programme (UNDP). ${ }^{13}$

${ }^{11}$ SADC Institutional Framework, available at http://www.sadc.int/index/browse/page/62

12 IGAD, a seven-country regional development organisation, superseded in 1996 the Intergovernmental Authority on Drought and Development founded in 1986. Its mission has three divisions: food security and environment protection, economic cooperation and integration, and promotion and maintenance of peace and security and humanitarian affairs. It consists of an inter-parliamentary union, a partners forum, heads of states session, NGO and civil society forum, executive secretary, committee of ambassadors, and various committees and councils of officials.

13 This is detailed in the SADC Thematic Coordination, available at http://www.sadc.int/icp/. The African Development Bank (ADB) is a regional multilateral development bank founded in 1964 to promote sustainable economic growth and to reduce poverty, whose shareholders include all 53 AU member states and 24 non-African countries, e.g. USA, UK, France, Germany, Saudi Arabia, Japan and China. The EC is the executive of the EU, controlled by 27 commissioners and staffed by 25000 civil servants in departments called directorates-general and services. The EIB, created in 1958 as its own legal personality and financial autonomy, is the long-term lending bank of the EU for projects to further policy objectives. The FAO is a specialist agency leading international efforts to defeat hunger, serving developed and less-developed countries, acting as a neutral forum to negotiate policy agreements and debate policy consisting of 191 countries, with the EU and the Faroe Islands as associate members. The 
In a similar vein, the EU is an organisational infrastructure of regional governance for Europe having various structures for combined and joint armed forces and for weapons procurement pronounced in formal treaties. Bi-lateral relations have existed for many years, on many levels and on many issues between the 27 member states of the EU and the 53 member states of the AU. From this, it has been natural for bilateral inter-regionalism to emerge on specific issues between the AU and EU regional organisational infrastructures in for instance as economic, cultural and political affairs. Given such common values, it has also been natural for this to evolve into trans-regionalism in certain areas, such as security affairs, as an underlying necessity for sustainable development.

\section{The origins of AU-EU trans-regionalism: from Cairo (2000) to Congo (2003)}

Reviewing and reflecting on the development of trans-regional organisational infrastructure in security affairs between the AU and EU in the first decade of the new millennium show the origins of AU-EU trans-regionalism arising with the Cairo Plan of Action (2000) following a summit meeting between heads of state of the EU and the Organisation of African Unity (OAU), the predecessor organisation of the AU that was disbanded in 2001. The purpose of the summit was "to work towards a new strategic dimension in the global partnership between Africa and Europe." 14

The summit reached a crucial decision towards a unique organisational infrastructure linking the two regional organisations on many levels when it recognised common values calling for security matters to be integrated with broader economic, cultural, development and political considerations. The Cairo Plan stressed that resolving conflicts (peace-building) would need to address multiple issues. The list includes the causes of conflicts, arms control on light weapons, the removal of land-mines, the non-proliferation treaty, fighting terrorism, the gender dimension for the active participation of women in diplomacy and at peace-

UNDP is the UN's global development network funded by voluntary contributions, providing staff, offering knowledge, experience and resources and working in 166 countries with their own solutions as they develop local capacity.

14 Africa-Europe summit under the aegis of the OAU and the EU/Cairo 3-4 April 2000: Cairo Plan of Action 4/4/2000 Nr: 107/4/00 available at http://www.consilium.europa.eu/uedocs/cms_data/docs/pressdata/en/er/0010 7-r4.en0.html 
negotiating tables, as well as food and health security and development issues including education. ${ }^{15}$

Such diversity could not be achieved through ad hoc measures and the first joint organisational infrastructure created was a senior officials group to oversee the co-ordination of security matters with economic, cultural, development and political issues. The first ministerial meeting (Brussels 11 October 2001) followed four meetings of the senior officials group and declared the need for a summit meeting. Given the previous month's terrorist attacks in New York and Washington, the AU and EU were able to find a new common ground to further cooperation in security affairs against terrorism. ${ }^{16}$

Further commonality ensued from the AU launch of the New African Initiative (NAI) to eradicate poverty and to place African countries, both individually and collectively, on a path of sustainable growth and development, while aiming to participate actively in the world economy and body politics. This vision was immediately enacted when a permanent link was set up between the different NAI tasks forces and the European Commission. ${ }^{17}$ The senior official group was tasked to link this with the Cairo Plan and another already existing process, the Cotonou Agreement (June 2000), that is the partnership agreement between the members of the African, Caribbean and Pacific Group of States based on three complementary pillars (development cooperation, economic and trade cooperation, and the political dimension). ${ }^{18}$ The subsequent Africa-Europe Ministerial Meeting (Burkina Faso, 28 November 2002) saw agreement that the method for transregionalism would be small groups representing each side and the facilitation of coordinators. The main format of dialogue would be meetings at the levels of

${ }^{15}$ Africa-Europe summit under the aegis of the OAU and the EU/Cairo 3-4 April 2000: Cairo Plan of Action 4/4/2000 Nr: 107/4/00 available at http://www.consilium.europa.eu/uedocs/cms_data/docs/pressdata/en/er/0010 7-r4.en0.html

${ }^{16}$ Africa-Europe Ministerial Conference, Brussels, 11 October 2001, available at http://www.consilium.europa.eu/uedocs/cms_data/docs/pressdata/en/er/1279 4.en1.pdf

${ }^{17}$ Statement of the meeting between African heads of state and the EU The New African Initiative 10 October 2001 available at http://www.consilium.europa.eu/ueDocs/cms_Data/docs/pressData/en/er/AC F2A66.pdf

${ }^{18}$ The Cotonou Agreement available at http://ec.europa.eu/development/geographical/cotonouintro_en.cfm 
officials as well as ad hoc groups that could also include NGOs and civil society. ${ }^{19}$

Desiring to be on an equitable level in this trans-regionalism, the AU took the initiative in establishing The African Peace and Security Architecture (Maputo 2002). This architecture would follow the policy pattern and structure of the EU European Security and Defence Policy (ESDP) for regional security, conflict management and civil crisis issues and hence would require, as exampled rather exemplified by the EU, a regional military force at brigade strength that could be deployed anywhere within Africa. Legitimacy was granted through the founding act of the AU establishing "the right of the Union to intervene in a member state pursuant to a decision of the Assembly in respect to grave circumstances namely: war crimes, genocide and crimes against humanity". ${ }^{20}$ A goal was set for 2010, for the African Stand-by Force (ASF) and its military and civilian crisis management tool, to reach its full operational capability. ${ }^{21}$

Sharing this with the EU as a trans-regional vision for peace, stability and development led to an intense educating and training cycle dedicated to the ASF decision, command and control structures. This cycle labelled Amani Africa (Swahili for Peace in Africa), based on an EU framework EURORECAMP, was adapted to the African reality. The training cycle was aimed at being a flexible tool allowing the AU to reach its objectives by providing an assessment and validation of its multidimensional peace-operation integrated management capacity, notably in terms of structures, procedures and available means. Correspondingly, to sustain this within the broader framework of the ESDP, the EU issued the European Security Strategy (2003). This pronounced security as the first condition to development where African security was voiced not only as a precondition for development of the African continent but also as being essential for European security. ${ }^{22}$ At the end of

19 Africa-Europe Ministerial Meeting in Burkina Faso (28 November 2002), available at http://www.consilium.europa.eu/uedocs/cms_data/docs/pressdata/en/er/7348 2.pdf

${ }^{20}$ Africa Union, Constitutive Act of the Union, Article (h) 4, 11 July 2000, available at http://www.au2002.gov.za/docs/key_oau/au_act.htm

${ }^{21}$ This goal has not yet been achieved though the organisation and structure is firmly established, see http://www.africa-union.org/root/au/AUC/Departments/PSC/Asf/asf.htm\#

22 Factsheet on EU support for peace and security in Africa, February 2005, available at http://www.consilium.europa.eu/showPage. $\operatorname{aspx} ? \mathrm{id}=400 \&$ lang $=\mathrm{en} \& \operatorname{mode}=\mathrm{g}$ 
2009, the cycle entered a crucial phase with the Political Strategic Seminar/Conference (POLSTRAT) where the African Peace and Security Architecture engaged its constituting bodies to develop a mandate and an integrated mission plan. A scenario, called CARANA, was specifically developed for Africa to simulate a crisis in a fictitious area which needed an AU engagement. ${ }^{23}$ The outcome allowed the AU to implement its developed plan during the command post exercise in 2010 as the culminating point of the Amani Africa cycle.

This process, indicative of trans-regional views, policies and activities, was an evolving one based on vital common values and interests within and between the $\mathrm{AU}$ and the EU and their respective member states. It built upon previous successes, the first of which was the operational and diplomatic success of the first autonomous EU military-led operation without recourse to NATO assets and the first EU security mission to Africa (Operation Artemis to Ituri in the Democratic Republic of the Congo lasting three months). The ability to undertake this mission was also a consequence of the development of the European Security and Defence Policy (ESDP) conceived for European security that required a rapid-reaction force. This force had just reached its preparedness level and was designed to be utilised for many different types of missions, including humanitarian. The EU operation commander was Major-General Neveux (France) and the EU force commander was Brigadier-General Thonier (France) who deployed 2000 troops from twelve EU member states and four other states. ${ }^{24}$ This EU military mission (12 June 2003 to 1 September 2003) took over from a UN mission as an interim force (UN Security Council Resolution 1484, 30 May 2003), contributing to the stabilisation of the security conditions and the improvement of the humanitarian situation in Bunia until the subsequent UN mission where it worked well with South African troops. ${ }^{25}$

Reviewing and reflecting on this mission, the EU-Africa Dialogue Ministerial Troika meeting (Rome 2003) noted the AU Peace Support Operation Facility (PSOF) as a valuable partner resulting in the European Commission

${ }^{23}$ CARANA Web-site, available at http://carana.amaniafricacycle.org/book/main.php

24 European Union Parliamentary Answers, 29 January 2009, available at http://www.europarl.europa.eu/sides/getAllAnswers.do?reference=E-20085747\&language $=\mathrm{PL}$

${ }^{25}$ Stephen Castle, Military mission to Africa is first for the EU, The Independent, 5 June 2003, available http://www.independent.co.uk/news/world/europe/military-mission-toafrica-is-first-for-the-eu-539787.html 
allocating $€ 250$ million to its development stating, "The functioning of this Facility will require an enhanced and permanent political EU-AU dialogue and continued consultations with the UN."26

\section{The security missions}

The success of Operation Artemis and the continuation of common vital interests of the $\mathrm{AU}$ and the EU led to eight subsequent security missions (civil and military) in Africa under the auspices of the ESDP and in collaboration with the AU:

- EUFOR RD Congo - lasting 25 April 2006 to 30 November 2006 in support of MONUC for elections.

- EUPOL Kinshasa - this force deployed 12 April 2005 to 31 December 2006 with mandate UNSCR 1493 (28 July 2003), which encouraged donors to support the establishment of an integrated Congolese police unit. The official request came on 20 October 2003 from the government of the DRC to the High Representative for the CFSP for EU assistance to set up an integrated policy unit HL to contribute to ensure the protection of the state institutions and to reinforce the internal security apparatus to help the Congolese National Police keep order during the transition to democracy, particularly during the electoral period in 2006.

- EU support for AMIS - deployed to Darfur, Sudan with an EU coordination cell in Addis Ababa, Ethiopia for the period 18 July 2005 to 31 December 2007. Its mandate was a letter dated 29 April 2005 from the President of the AU Commission to the Secretary-General/High Representative (SG/HR) hoping to be able to count on the substantial support of the EU and its member states to the efforts of the AU and to the reinforcement of AMIS II. UNSCR 1556 (30 July 2004) welcomed the contributions already made, notably by the EU, to support the AU-led operation. The EU made available equipment and assets, provided planning and technical assistance, sent military observers, trained African troops, helped with tactical and strategic transportation and provided police assistance and training. This concluded when AMIS merged into UNAMID.

${ }^{26}$ EU-Africa Dialogue Ministerial Troika 10 November 2003 Rome, available at http://www.consilium.europa.eu/uedocs/cms_data/docs/pressdata/en/er/7792 3.pdf 
- EUFOR CHAD/RCA - deployed to Chad and to the Central African Republic (28 January 2008 to 15 March 2009). The mandate was UN Security Council Resolution 1778 (25 September 2007) authorising the EU to deploy a force. UNSCR 1834 (24 September 2008) welcomed the EU deployment. The EU Operation Commander General Nash (Ireland) and the EU Force Commander General Ganascia (France) deployed 3700 troops (14 EU member states present in the field, 18 in theatre, and 24 at the Operations Headquarters; 3 other states contributing). ${ }^{27}$ The force successfully contributed in protecting civilians in danger, particularly refugees and displaced persons, protected UN personnel, facilities installations and equipment, ensured the security and freedom of movement of its own staff, UN staff and associated personnel, facilitated the delivery of humanitarian aid and the free movement of humanitarian personnel by helping to improve security in the area of operations. It handed its mission over to a UN force MINURCAT in March 2009 although some 2000 EU troops who served under the EU banner continued under the MINURCAT banner.

- EUPOL RD CONGO - originally intended to last 2 July 2007 to 31 June 2009, had its mandate extended until 30 June 2010 as a follow-on from EUPOL Kinshasa whose mandate was an official invitation (26 April 2005) from the DRC government to the Secretary-General/High Representative for CFSP with a view to obtaining assistance from the EU through the establishment of a team to provide the DRC with advice and assistance for security sector reform. The extended mandate resulted in the formation of a project cell with a complementary approach in order to implement small projects within the mission's mandate, to provide reinforced coordination and technical assistance to EU member states and other states.

- EUSEC RD CONGO - launched on 8 June 2005 with a mandate that ran until 30 September 2009 to restore governance in general and defence reform in particular by creating lasting conditions for stability in DRC. It also had a mandate to implement or supervise projects in areas such as gender, human rights, health and infrastructure, financed or initiated by member states and/or the EC. This mission also played a part in the efforts by the EU special representative HL for the African Great Lakes Region to

27 European Union parliamentary answers, 29 January 2009, available at http://www.europarl.europa.eu/sides/getAllAnswers.do?reference=E-2008$5747 \&$ language $=\mathrm{PL}$ 
implement the statements of commitment for the Kivus.

- EU SSR Guinea-Bissau - the EU mission in support of security sector reform in Guinea-Bissau had an original mandate from 12 February 2008 to 31 May 2009 from a report by the UN Secretary-General (28 September 2007) underlying Guinea-Bissau's inability to combat drug trafficking by itself. It called for technical and financial support from regional and international partners furthered by a letter (10 January 2008) from the government of Guinea-Bissau inviting the EU to deploy a SSR mission in Guinea-Bissau. The force provided advice and assistance on reform of the security sector in order to contribute to creating the conditions for implementation of the National Security Sector Reform Strategy. The mandate was extended until November 2009 with the purpose to fully accomplish the mission's original mandate, to further explore the capacity and the commitment of the new government to carry forward the reform process, and to assess the willingness of the international community to support it.

- EU NAVFOR Somalia - this is the first EU maritime operation, conducted in the framework of ESDP deployed 8 December 2008 to 8 December 2009. The EU Council decided on 15 June 2009 to extend the operation's mandate for another year to 13 December 2010 in conjunction with a mandate of UN Security Council Resolutions 1814 (2008), 1816 (2008), 1838 (2008) and 1846 (2008) in order to contribute to the protection of vessels of the World Food Programme (WFP) delivering food aid to displaced persons in Somalia, the protection of vulnerable vessels, and the deterrence, prevention and repression of acts of piracy and armed robbery off the Somali coast. This mission is closely linked to financial and training support provided to the AU AMISOM mission with the EU. The first operation commander was Admiral Jones (UK), succeeded by Rear Admiral Peter Hudson (UK) on 13 August 2009. The first EU force commander was Commodore Papaioannou (Greece) succeeded by Commodore Pieter Bindt (Netherlands). The military capabilities and personnel involved were six frigates and three maritime patrol aircraft entailing 1200 people taking part in the operation. To date, all WFP ships protected by the EUNAVFOR have arrived safely at their destinations. The EU also established 10 cooperative frameworks and arrangements to enable the force to work with the international merchant community and other naval forces deployed in the region. Arrangements were also reached concerning the judicial treatment of captured pirates with 
Kenya on subsequent prosecution.

All the EU missions in Africa are important in their own right for having achieved the specific mission goals. This is important because the collective success furthered sustaining the grand strategy of security and development for Africa and also because of the evolving step-by-step process of establishing a common transregional organisational infrastructure (secretariat for research, policy planning, preparation and coordination of meetings and implementation of decisions).

Some of these missions (EUFOR RD Congo, EUSEC RD CONGO, EU SSR Guinea-Bissau), although under ESDP, have been labelled EU civilian missions since they have not involved the deployment of a fully-fledged military force. They have involved policing, rule of law, border assistance and monitoring and security sector reform. Since June 2007, however, they are under a single chain of command. The current civilian operations commander is a Dutch national, Mr Klompenhouwer, who exercises command and control at strategic level for the planning and conduct of all civilian crisis management operations, under the political control and strategic direction of the Political and Security Committee and the overall authority of the High Representative for EU CFSP.

Common to all the EU security missions has been a UN mandate. Frequently, existing EU forces on the ground continue as UN forces on the ground (or vice versa) at the handover of authority and continue the same or similar tasks. (e.g. EUFOR CHAD/RCA). This is because EU countries have limited all-volunteer armed forces although they have multiple commitments of these forces, and are frequently over-stretched to meet these. The practical benefit is that individual soldiers and units are able to apply their experience at the tactical level from an EU mission to a UN or NATO mission or vice versa to the benefit of all.

These EU security-related missions in Africa compare with eight EU security missions in Europe (six in the Balkans, two in Georgia), three security missions in the Middle East (one in Iraq, two for the Palestinians), one mission to Afghanistan, and one mission to Indonesia. Of these missions, 12 are ongoing (four in Africa, three in the Balkans, two for the Palestinians, one in Georgia, one in Afghanistan, one in Iraq) and 10 have been concluded successfully. ${ }^{28}$ Therefore, Africa as a cause of concern for EU security missions predominates with nine out of

${ }^{28}$ European defence and security policy (ESDP), available at http://www.consilium.europa.eu/showPage.aspx?id=268\&lang=en 
22 security missions.

With the growth of missions to Africa, the EU established the ATHENA mechanism to administer the financing of common costs managed under the authority of a special committee composed of representatives of 26 member states, who are accountable towards their own national parliaments via their respective ministers (Denmark has opted out). The remainder of the expenditure is financed directly by the member states, which contribute forces to the operations. While ESDP civilian missions are financed under the CFSP budget heading, ESDP operations having military or defence implications cannot be financed from the Community budget (cf. art. $28 \mathrm{TEU}$ ) and are thus financed by member states. ${ }^{29}$

\section{The joint AU-EU strategy for Africa}

Evident at the EU-Africa Ministerial Meeting (Dublin Ireland, April 2004), was the recognition of the role that regional and sub-regional organisations could play in the maintenance of international peace and security where the operationalisation of the AU Peace and Security Council was an important step. ${ }^{30}$ Treating this with the seriousness that it deserved was a declaration on multilateralism including the joint commitment to reinforcing cooperation with each other and with the UN. Inherent was the understanding that security and economics are intertwined. This was reiterated when a joint AU-European commission monitoring mechanism HL was established as an instrument of development voicing security as the essential basis for development. ${ }^{31}$ Views were exchanged at the third meeting of the African and European Troikas (Addis Ababa, December 2004) resulting in EU financial assistance to the AU mission to Darfur (AMIS) elaborating the need to

${ }^{29}$ EU Council secretariat fact-sheet, Financing of ESDP Operations, June 2007, available at http://www.consilium.europa.eu/uedocs/cmsUpload/ATHENA_june_2007.p df

${ }^{30}$ EU Council press release, EU-Africa ministerial meeting, Dublin Ireland, 1 April 2004, available at http://www.consilium.europa.eu/uedocs/cms_data/docs/pressdata/en/er/7981 4.pdf

31 EU-Africa Dialogue, third meeting of the African and European Troikas 4 December 2004, available at http://www.consilium.europa.eu/uedocs/cms_data/docs/pressdata/en/er/8296 9.pdf Page 4 and Page 6 
expand the deployment of EU security missions especially in Sudan and Chad. ${ }^{32}$

The European Council made a crucial decision confirming the common values between the AU and EU of security as the basis for development when it adopted the EU Strategy for Africa in December 2005. The emphasis of this strategy was for the EU to address Africa as a single regional entity. ${ }^{33}$ This was an evolutionary decision as part of the aforementioned process that had commenced with the Cairo Plan (2000). Catalysts to the decision was the success of Operation Artemis, the migration of the AU from the OAU, the formation of the New Partnership for Africa's Development (NEPAD), the reinforced role of Africa's Regional Economic Communities (REC) and the emergence of a new generation of African leaders. In adopting this strategy, it was intended that all EU policies and activities towards and with Africa would be linked to each other. The grand strategy of the EU political stance to Africa was also solidified within the military component defined under the auspices of the ESDP. This grand strategy would be achieved on the basis of the principle of subsidiarity; only matters which would be dealt with less effectively at a lower level should be reserved for a higher level of governance. The EU also aimed to enhance intra-African solidarity between these three levels and to raise dialogue with the African continent as a whole to the highest political level. ${ }^{34}$ Such a process is clearly an established means of diplomatic protocol and process; however, in order to succeed, it will also need to engage with African civil society structures.

To implement this, the institutions of the EU initiated dialogue with the AU and established joint programmes leading towards singular organisational infrastructure compared to the previous common infrastructure. As part of this strategy, it was declared that peace and security were the first essential prerequisites of sustainable development. ${ }^{35}$ An important step was to amalgamate existing

32 EU-Africa Dialogue, third meeting of the African and European Troikas 4 December 2004, available at http://www.consilium.europa.eu/uedocs/cms_data/docs/pressdata/en/er/8296 9.pdf

${ }^{33}$ Commission of the European communities: EU Strategy for Africa, Brussels, 12 October 2005, COM (2005) 489 Final available at http://ec.europa.eu/development/icenter/repository/04_eu_strategy_for_afric a_12_10_2005_en.pdf

${ }^{34}$ EU Strategy for Africa (2005), available at http://europa.eu/scadplus/leg/en/lvb/r12540.htm

${ }^{35}$ EUROPA Press Release, European Commission adopts "European Union Strategy 
agreements and processes that were successful between various European and African and third-party states that included the Cotonou Agreement, the Trade Development and Cooperation Agreement, the Euro-Mediterranean Partnership, the European Neighbourhood Policy, and the CFSP/ESDP. This infrastructure development was simultaneous with the deployment of three EU military missions to the DRC, namely EUFOR RD Congo, EUPOL Kinshasa and EUSEC RD CONGO and the EU support together with NATO and the UN to the AU mission AMIS in Sudan.

A review and a reflection of the progress of these agreements and activities, in October 2006, showed that the EU-Africa Dialogue had intensified requiring an interlocking system of peacekeeping capacities through a ten-year building plan. To justify such a military strategy, the overriding political goal pronounced was promotion of the UN Millennium Development Goals (MDG) in Africa. In doing so, any EU military or police force could also act with states outside of both Africa and Europe as exemplified by Russia and Ukraine (who provided helicopters and pilots to some security missions) and could exchange roles for UN forces, either handing over to them or taking over from them (as was the case when EUFOR CHAD/RCA handed over to MINURCAT). This generated a global option with the EU stating it was willing to cooperate and operate with states and institutions of governance from any other region. The review detailed how over $€ 500$ million was being allocated to various programmes, some of which were in addition to the aforementioned security missions, for example to the UNDP for a disarmament programme it was managing in Congo Brazzaville as well as to post conflict reconstruction. ${ }^{36}$ This was not surprising since the EU is the largest donor to Africa and is also Africa's biggest trading partner amounting, for example, to $€ 144$ billion in the year 2000 , which was five times bigger than intra-Africa trade. ${ }^{37}$

for Africa" 12 October 2005, available at http://europa.eu/rapid/pressReleasesAction.do?reference=IP/05/1260\&forma $\mathrm{t}=$ HTML\&aged $=0$ \&language $=$ EN\&guiLanguage $=\mathrm{en}$

${ }^{36}$ European Union fact-sheet, Progress report on the implementation of the EU Strategy for Africa, October 2006, available at http://www.consilium.europa.eu/uedocs/cmsUpload/061017Africa_Strategy.pdf

${ }^{37}$ European Union Factsheet, EU Support for Peace and Security in Africa, February 2005, available at http://www.consilium.europa.eu/uedocs/cmsUpload/Africa.pdf 
Beyond donor-recipient relations in establishing AU-EU trans-regional interdependence

The next important watershed of AU-EU trans-regionalism was the second AU-EU Summit on security relations held in Lisbon Portugal (December 2007) that reflected on relations since the Cairo Conference (2000). The debate focused on an increased understanding of the vital inter-dependence between the AU and the EU. Agreement was reached to build a new strategic political partnership for the future, overcoming the traditional donor-recipient relationship, and to build on common values and goals in pursuit of peace and stability, democracy and rule of law, progress and development. ${ }^{38}$ This was a landmark decision giving the AU an equitable footing in any trans-regional institution. The EU was determined to give such a new strategic partnership the necessary means and instruments to fulfil the joint strategy and action plan. ${ }^{39}$ HL Eight partnership programmes under the EUAfrica action plan were established where security was given as a pre-requisite for development. $^{40}$

By the time that the $10^{\text {th }}$ Africa-EU ministerial TROIKA meeting took place in Brussels (September 2008), the positions of the EU special representative and head of delegation of the European commission delegation HL to the AU had been created and located in Addis Ababa, Ethiopia. It was clear from the statement of that meeting that unique security organisational infrastructure (secretariat for research, policy planning, preparation and coordination of meetings and implementation of

${ }^{38}$ EU Africa Summit - Lisbon Declaration 9/12/2007 - Press: 290 Nr: 16343/07 available at

http://www.consilium.europa.eu/uedocs/cms_data/docs/pressdata/en/er/9749 4.pdf

${ }^{39}$ First Action Plan for the implementation $\mathrm{f}$ the Africa-Eu Strategic Partnership available at

http://docs.google.com/viewer?a=v\&q=cache:xNRA3ImUVMsJ:www.africa -eu-

partnership.org/pdf/eas2007_action_plan_2008_2010_en.pdf+eu+africaction +plan\&hl=en\&pid=bl\&srcid=ADGEESjEnyMiR9I7nbkH_f_C4iQigZ2LH11 p3d_h6CotRIZFXIQazt5QuPtoXg38plYoCkWhbkLpxDQ17cw7Y0i40HL47 QvJKxEVJhpVPaTVSp4miljIAJycrdY3KviDHZe5FOnhPk_T\&sig=AHIEtb QQJebMhGgAy7FI4AgWQos3Gtazmw

${ }^{40}$ Council conclusions on "One year after Lisbon: The Africa-EU partnership at work", available at http://www.consilium.europa.eu/uedocs/cmsUpload/EUAfricaDialogue103904.pdf Paragraph 3 
decisions) had been established to coordinate the various AU-EU collaborations in security affairs. This included the migration of AMIS into UNAMID (Sudan), the deployment of EUFOR CHAD/RC on the Sudan/Chad border, AMISOM (Somalia), EU SSR Guinea-Bissau, continuing missions in the DRC as well as diplomatic efforts relating to the internal instability of Zimbabwe, piracy off the Somali coast and the coup d'état in Mauritania. Although security missions were not deployed to the crises in Côte d'Ivoire, it was discussed intensively in EU forums, as was the Ethiopian-Eritrean border issue. Given that the AU and EU had recognised their equitable footing in such meetings, the EU briefed AU leaders regarding security issues of concern in Europe, which included Georgia and Kosovo. ${ }^{41}$

These meetings showed that the process of AU-EU trans-regional relations as still being in its infancy, given the wide cleavage between the positions of the AU and EU respectively, especially on the case of Zimbabwe. This does not reflect a failure in trans-regional security arrangements but rather shows that a healthy organisation has the maturity to be able to voice opinions, open debates and reach an understanding of common problems with a view to solving them. NATO, for example has always been able to do so with the ongoing disputes between two of its member states, Greece and Turkey.

The 2007 declaration, the experiences from the military missions, the numerous joint, common and singular working groups, the various ministerial and summit meetings and the policy goals were instrumental in initiating EURORECAMP which, as already mentioned, was a joint decision in implementing the 2010 goal for the ASF where the Lisbon Agreement enabled the means for a joint training cycle with a budget of $€ 300$ million. The cycle development would rely on a scenario allowing the conduct of crisis management from the diplomatic phase to the deployment of an integrated (military, civil and police) intervention force. In practice, this would necessitate a unique trans-regional organisational infrastructure. The first phase commenced with an initiating conference on 21 November 2008 at the AU in Addis Ababa, followed by a contributors' conference (Brussels 6 February 2009) organised by the Joint Expert Group with a completion target for June $2010{ }^{42}$ This would be monitored by a Common Interactive Watch and Participation

${ }^{41}$ 10th Africa-EU ministerial TROIKA meeting, Brussels, 16 September 2008, http://www.consilium.europa.eu/uedocs/cmsUpload/AfricaEU_Troika_102801.pdf

${ }^{42}$ EURORCAMP AMANI AFRICA (2008-2010), available at http://www.amaniafricacycle.org/spip.php?article8 
mechanism. ${ }^{43}$ At the same time, a tri-lateral dialogue was initiated between the AU, EU and China with the aim of promoting peace and security and contributing towards the efforts of the Millennium Development Goals (MDG) for Africa in light of the Forum on China-Africa Cooperation framework (FOCAC), established in 2006 as a result of the ever increasing role of China in Africa. Both the AU and the EU emphasised that particular attention should be given to cooperation in the area of peace and security, and that development and security were interdependent. ${ }^{44}$

\section{Conclusion}

Justification of any country's foreign policy and indeed any trans-regional security organisation can be measured in terms of commitment and in terms of success. The success of the ESDP European Security and Defence Policy can be measured through the functioning of nine security missions to Africa. The deployment of these missions engaged 26 EU member states and involved 9000 troops (with no deaths or injuries as a result of hostile action). The commitment of European civil society is noted through the unchallenged financial commitment by its taxpayers that can be detailed as follows: ${ }^{45}$

- Common costs administered by ATHENA in security operations:

i. EU supporting action to AMIS: $€ 1,3$ million (2007);

ii. EUFOR RD Congo: $€ 23$ million (2006);

iii. EUSEC RD Congo: financing of a civilian project to reform the chain of payment in the DRC until the mission could be accommodated under the CFSP budget: $€ 0,9$ million (2005);

iv. EUFOR CHAD/RCA: $€ 120$ million (2008); and

v. EU NAVFOR Somalia: $€ 8,3$ million (2009).

- As far as civilian missions are concerned, they are financed under the EC

${ }^{43}$ Joint Communique 11th Africa-EU ministerial Troika meeting, 20-21 November 2008, available at http://www.consilium.europa.eu/uedocs/cms_Data/docs/pressdata/en/er/1042 45.pdf

44 Council conclusions on the tri-lateral dialogue were initiated between the European Union, Africa and China, available at http://www.consilium.europa.eu/uedocs/cmsUpload/Eu-Africa103901.pdf

${ }^{45}$ European Union parliamentary answers, 29 January 2009, available at http://www.europarl.europa.eu/sides/getAllAnswers.do?reference=E-2008$5747 \&$ language $=\mathrm{PL}$ 
CFSP budget heading, which is administered by the European Commission. According to council secretariat HL estimates, the total budget of ongoing missions (multi-annual commitments) is $€ 534555000$.

Similarly, the African Union has shown its commitments on a continentalwide basis, especially through the activities of sub-regional organisations such as ECOWAS and the SADC. These have played an important role in creating regional security frameworks notable for enhancing dialogue. The AU has played an active and equitable partner role with the EU over the decade (2000-2010) through various combined and hybrid security missions. The numerous summits, meetings, committees and working groups has led to the emergence of a trans-regional organisational infrastructure (secretariat) between the $\mathrm{AU}$ and the EU for the purpose of research, policy planning, preparation and coordination of meetings and the implementation of decisions.

Simultaneous to the intensive diplomatic and policy process and the nine security missions, there has also been training and procurement for long-range planning to suit the strategy that security is the prerequisite for sustainable development and related issues, such as democratic governance, trade, regional integration, energy and food requirements, the environment, economics, migration, mobility, employment and health, human rights as well as state territorial requirements. Given the necessities and successes mentioned in this article, there is no doubt that AU-EU trans-regionalism development will be simultaneous with the evolving structures within each regional organisation that are aimed to strengthen integration and reduce conflict through the sharing of resources and territory that were previously causes of conflict.

The above details and analysis of AU-EU trans-regionalism must be placed in a wider context. It co-exists with other endeavours offering a glimpse of a process of globalisation. Many of the AU-EU security missions have a United Nations mandate, and some take-over or hand-over to UN forces. In some cases, the AU-EU forces emerge from or join with the UN forces. There are also other trans-regional endeavours that include working with other regional for a, e.g. NATO and individual states outside of Africa and Europe as partners, e.g. Russia and China (a tri-lateral dialogue and process is underway). 